\title{
PEMANFAATAN LAHAN MASYARAKAT DENGAN BUDIDAYA KANGKUNG DI KELURAHAN SAKO BARU KOTA PALEMBANG
}

\author{
Diah Putri Islamy ${ }^{1}$ \\ Trecy Austin ${ }^{2 *}$ \\ Syaparman ${ }^{3}$ \\ 1,2*Ilmu Administrasi Negara, STISIPOL Candradimuka, Palembang, Indonesia \\ 3Ilmu Politik, STISIPOL Candradimuka, Palembang, Indonesia \\ diahputribae123@gmail.com ${ }^{1}$ \\ trecy.austin@gmail.com ${ }^{2}$ ) \\ sya.parman@gmail.com ${ }^{3)}$
}

Kata Kunci: [Pemanfaatan lahan, Budidaya Kangkung]

\begin{abstract}
Abstrak: Membangun ketahanan pangan keluarga di saat pandemi covid 19 sangat diperlukan Masyarakat. Perubahan iklim dapat menimbul kan resiko besar bagi keamanan pangan, dan pengembangan ekonomi. Lahan kosong yang di Kelurahan Sako Baru RW.001 akan dimanfaatkan untuk membudidayakan tanaman kangkung selama pandemi covid 19 bersama kelompok tani fokus menghasilkan kangkung dilakukan sejak penaburan bibit sampai panen. Pemanfaatan lahan kosong digunakan agar lahan yang terbengkalai atau kosong dapat dimanfaatkan menjadi lahan menanam tanaman yang bermanfaat bagi masyarakat. Dalam program kerja dari STISIPOL Candradimuka Palembang melihat potensi lahan kosong di sekitar lingkungan warga yang dapat dimanfaatkan ditanami sayur. Maksud dan Tujuan dari kegiatan Pemberdayaan Masyarakat ini untuk membuka pola pikir masyarakat terhadap lahan yang masih kosong agar bisa dimanfaatkan dan berguna bagi masyarakat, ditambah lagi bisa menjadi nilai tambah ekonomis bagi Masyarakat terutama Masyarakat di RW 001 Kelurahan Sako Kecamatan Sako Kota Palembang.
\end{abstract}

Published by:

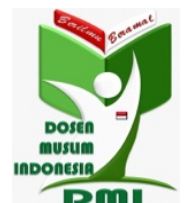

Copyright (C) 2022 The Author(s)

This article is licensed under CC BY 4.0 License (cc) $\mathrm{BY}$ 


\section{Pendahuluan}

Perubahan iklim dapat menimbul kan risiko besar bagi kesehatan manusia, keamanan pangan, dan pengembangan ekonomi. Pemberdayaan Masyarakat ini menitikkan kepada Program Kampung Iklim, dengan pemanfaatan Lahan kosong yang ada di Kelurahan Sako Baru RW.001 untuk membudidayakan tanaman kangkung bersama kelompok tani dalam hal pembukaan lahan sekaligus proses produksi yang bermanfaat untuk masyarakat sekitar. (Kementerian Lingkungan Hidup dan Kehutanan Direktorat Pengendalian Perubahan Iklim, 2017)

Pemanfaatan lahan kosong digunakan agar lahan yang terbengkalai atau kosong dapat dimanfaatkan menjadi lahan menanam tanaman yang bermanfaat bagi masyarakat. Kami melihat potensi lahan kosong di sekitar lingkungan warga yang dapat dimanfaatkan ditanami sayur seperti tanaman Kangkung. Pemberdayaan masyarakat dalam mengelola lahan kosong menjadi lahan hijau menggunakan bagian dari pelaksanaan Program Kampung Iklim yang mengedepankan ramah lingkungan dan yang pasti bermanfaat bagi Masyarakat sekitar. Pemanfaatan lahan kosong atau sempit dapat dilakukan dengan berbagai cara antara lain dengan memakai Lahan Kosong. Pemanfaatan pekarangan rumah sebagai sarana budidaya tanaman, dan sebagainya. (Austin \& Marleni, 2021)

Kelurahan sako dipecah menjadi dua kelurahan yaitu, Sako dan Sako Baru sehingga terdiri dari empat Kelurahan, yaitu Sako, Sukamaju, Sialang, dan Sako Baru. Sampai saat ini, Kecamatan Sako Terdiri dari empat Kelurahan, yaitu Sako, Sialang, Sukamaju, dan Sako Baru dengan wilayah 17.907 Km. (Feriyanto, 2021)

Maksud dan Tujuan dari kegiatan Pemberdayaan Masyarakat ini yaitu untuk membuka pola pikir masyarakat terhadap lahan yang masih kosong agar bisa dimanfaatkan dan berguna bagi masyarakat, ditambah lagi bisa menjadi nilai tambah ekonomis bagi Masyarakat terutama Masyarakat di RW.001 Kelurahan Sako Kecamatan Sako Kota Palembang. Pengoptimalan lahan kosong di RW. 001 Kelurahan Sako baru Kecamatan Sako Kota Palembang bisa di manfaatkan menjadi lahan yang produktif sesuai substansi nya produktivitas, berkeadilan dengan berorientasi kepada kesejahteraan Masyarakat. Mitra yang juga ikut dilibatkan dalam kegiatan ini adalah Kelompok tani Kelurahan Sako Baru Palembang.

\section{Metode Pelaksanaan}

\section{Tempat dan Waktu}

Lokasi yang menjadi tempat pengabdian masyarakat RW. 001 Kelurahan Sako Baru Kecamatan Sako Palembang, Kelurahan sako dipecah menjadi dua kelurahan yaitu, Sako dan Sako Baru sehingga terdiri dari empat Kelurahan, yaitu Sako, Sukamaju, Sialang, dan Sako Baru. Sampai saat ini, Kecamatan Sako Terdiri dari empat Kelurahan, yaitu Sako, Sialang, Sukamaju, dan Sako Baru dengan wilayah 17.907km (Lihat Gambar 1). 


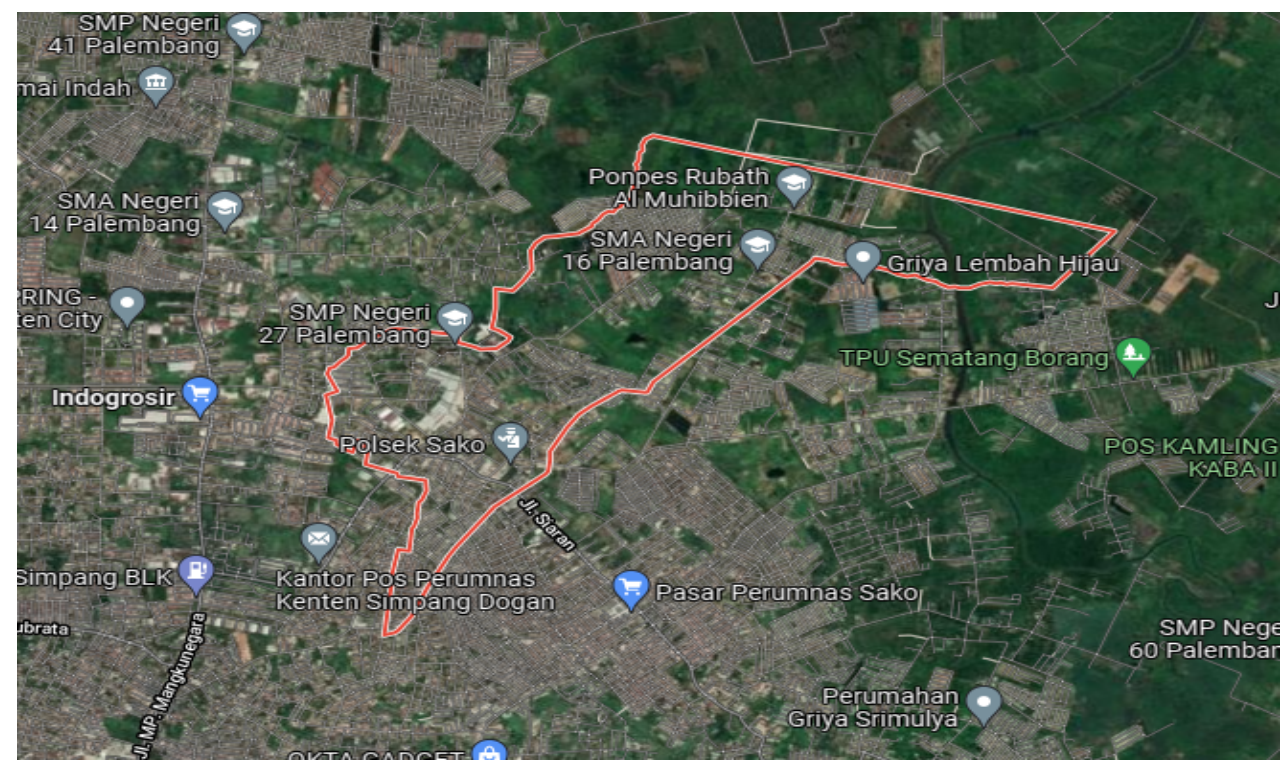

Gambar 1. Peta Lokasi Kelurahan Sako Baru

\section{Khalayak Sasaran}

Kegiatan ini mengikutsertakan Masyarakat dan Kelompok Tani di RW. 001 Kelurahan Sako Baru yang sebagian besar berdampak Covid 19. Adapun data dari Masyarakat berdasarkan Usia dapat dilihat di Tabel 2.

Tabel 2. Data Masyarakat Berdasarkan Usia

\begin{tabular}{|c|c|c|c|c|c|c|}
\hline \multirow[t]{2}{*}{ No } & \multirow[t]{2}{*}{ KelompokUsia } & \multicolumn{4}{|c|}{ JumlahPenduduk } & \multirow[t]{2}{*}{$\begin{array}{c}\text { Jumlah } \\
\text { Total }\end{array}$} \\
\hline & & $\mathbf{L}$ & Persentase & $\mathbf{P}$ & Persentase & \\
\hline 1 & $0-4$ & 492 & $53 \%$ & 435 & $46 \%$ & 927 \\
\hline 2 & $5-9$ & 321 & $48 \%$ & 347 & $51 \%$ & 668 \\
\hline 3 & $10-14$ & 324 & $47 \%$ & 355 & $52 \%$ & 679 \\
\hline 4 & $15-19$ & 362 & $50 \%$ & 359 & $49 \%$ & 721 \\
\hline 5 & $20-24$ & 280 & $50 \%$ & 239 & $46 \%$ & 519 \\
\hline 6 & $25-29$ & 309 & $49 \%$ & 321 & $50 \%$ & 630 \\
\hline 7 & $30-34$ & 316 & $60 \%$ & 275 & $46 \%$ & 591 \\
\hline 8 & $35-39$ & 248 & $43 \%$ & 328 & $56 \%$ & 576 \\
\hline 9 & $40-44$ & 227 & $49 \%$ & 235 & $50 \%$ & 462 \\
\hline 10 & $45-49$ & 231 & $49 \%$ & 234 & $50 \%$ & 465 \\
\hline 11 & $50-54$ & 283 & $56 \%$ & 220 & $43 \%$ & 503 \\
\hline 12 & $55-59$ & 273 & $56 \%$ & 211 & $43 \%$ & 484 \\
\hline 13 & $60-64$ & 37 & $28 \%$ & 91 & $70 \%$ & 128 \\
\hline 14 & $65-69$ & 50 & $49 \%$ & 52 & $50 \%$ & 102 \\
\hline 15 & $70-74$ & 48 & $50 \%$ & 47 & $49 \%$ & 95 \\
\hline 16 & +75 & 3801 & $50 \%$ & 3749 & $49 \%$ & 7550 \\
\hline
\end{tabular}


Berdasarkan Tabel 2. Kami tidak mengajak seluruh Masyarakat RW. 001, melainkan Masyarakat yang dipilih terlebih dahulu oleh Ketua RW. 001 Kelurahan Sako Baru dengan jumlah Masyarakat kurang lebih 50 orang. Waktu Pelaksanaan kegiatan Pemberdayaan Masyarakat dilakukan selama bulan September dan Bulan Oktober 2021 yang mana disusun berdasarkan kondisi terkini di lapangan dengan rincian dapat dilihat pada Tabel 3.

Tabel 3. Waktu Kegiatan

\begin{tabular}{l|l|l|l}
\hline \multicolumn{3}{c}{ BULAN SEPTEMBER } & \\
\hline Survey lokasi lurah dan Ketua RW. & & & \\
001 & & & \\
Koordinasi dengan Masyarakat & & & \\
dan Kelompok Tani tentang & & & \\
perencanaan program kegiatan & & & \\
Pemberdayaan Masyarakat yang & & & \\
akan dilakukan & & & \\
Pelaksanaan Kegiatan berupa & & & \\
pendampingan praktek secara & & & \\
langsung. & & & \\
1. Persiapan Lahan & & \\
2. Pembukaan lahan & & \\
3. Perisapan bibit, dan & & \\
4. Persiapan pupuk & & & \\
\hline
\end{tabular}

BULAN OKTOBER

\begin{tabular}{|c|}
\hline $\begin{array}{l}\text { Masyarakat mandiri dan } \\
\text { menghasilkan produk } \\
\text { Produk dapat di konsumsi oleh } \\
\text { Masyarakat }\end{array}$ \\
\hline $\begin{array}{l}\text { Penutupan Acara Pemberdayaan } \\
\text { Masyarakat }\end{array}$ \\
\hline
\end{tabular}

Sumber: Diolah Penulis Tahun 2021

\section{Metode Pengabdian}

Kegiatan Pemberdayaan Masyarakat dilaksanakan dengan melakukan kegiatan pelatihan, pendampingan serta penyuluhan dalam pmeanfaatan lahan kosong Masyarakat. Kegiatan yang dilaksanakan meliputi, Pemberdayaan masyarakat untuk peningkatan perubahan pola pikir masyarakat agar berkembang dan bertahan di masa pandemi covid 19, dan Pelestarian lingkungan Masyarakat bersama kelompok Tani. Secara rinci metode pelaksanaan kegiatan diantaranya yaitu:

1. Kajian Literatur dilakukan untuk mengetahui beberapa hal mengenai Program Kampung Iklim seperti: Adaptasi, dan Mitigasi.

2. Survei Lokasi menjadi langkah awal supaya kegiatan dapat berjalan lancar.

3. Sosialisasi di awal kegiatan kepada Ketua RT di RW 001, tahapan kegiatan dan jadwal kegiatan.

4. Edukasi secara tatap muka terhadap Masyarakat yang kurang dari 50 orang, karena masih masa pandemi covid 19. 
5. Persiapan Lahan, pembukaan lahan, persiapan bibit, dan persiapan pupuk.

6. Pendampingan dan Prakter Langsung

Penyelesaian masalah ini tidak semata-mata dilakukan hanya untuk kebutuhan penulisan, namun dilaksanakan secara langsung dengan pendampingan dan praktek langsung dilakukan selama dua bulan, Bulan September dan Oktober.

\section{Indikator Keberhasilan}

Indikator keberhasilan produk kegiatan Pemberdayaan Masyarakat ini, yaitu:

1. Terlaksananya kegiatan Pembudidayaan Kangkung di Kelurahan Sako Baru Kecamatan Sako sebagai media edukasi dan wisata.

2. Meningkatnya produksi pangan di lahan Masyarakat

3. Meningkatkan pengetahuan dan motivasi serta minat masyarakat tetang budidaya tanaman

4. Meningkatkan kesadaran masyarakat dalam menjaga dan melestarikan lingkungan selama pandemi Covid 19.

5. Meningkatkan tingkat konsumsi sayur dan mengurangi penularan wabah penyakit

6. Dihasilkan video dokumentasi tentang penerapan pemanfaatan lahan kosong Masyarakat melalui budidaya sayur.

\section{Hasil dan Pembahasan}

Memanfaatkan lahan kosong untuk membudidayakan tanaman sayuran kangkung. Dalam hal ini pertama-tama kegiatan yang kami lakukan adalah melakukan pertemuan dengan pihak kelurahan yang ada serta melakukan survey mengenai kependudukan, demografis dan keadaan lahan lingkungan di sekitar. Observasi yang kami lakukan di wilayah Kelurahan Sako Baru ini menghasilkan bahwa potensi yang ada diantaranya Sayuran Kangkung. (Inang Pambudi \& Yudha Erlangga, 2018)

Lahan yang akan digarap dan dikembangkan ialah Tanaman Kangkung. Di Jalan Karya Muda 1 Lorong Sepadat RW.001 Kelurahan Sako Baru Kecamatan Sako Kota Palembang. Menurut kami program ini mempunyai peluang untuk berkembang namun ada beberapa hal yang memang harus di evaluasi dan juga dikembangkan agar kedepannya lebih maju dan berkembang pesat dikalangan Era New Normal. Selanjutnya kami melihat proses pertumbahan hingga panen dari tanaman kangkung ini, dalam hal ini kami memberikan masukan mengenai inovasi atau ide agar tanaman tersebut bisa bermanfaat bagi masyarakat sekitar. Adapun hasil dari Pembedayaan Masyarakat dapat dilihat pada Gambar dibawah ini.

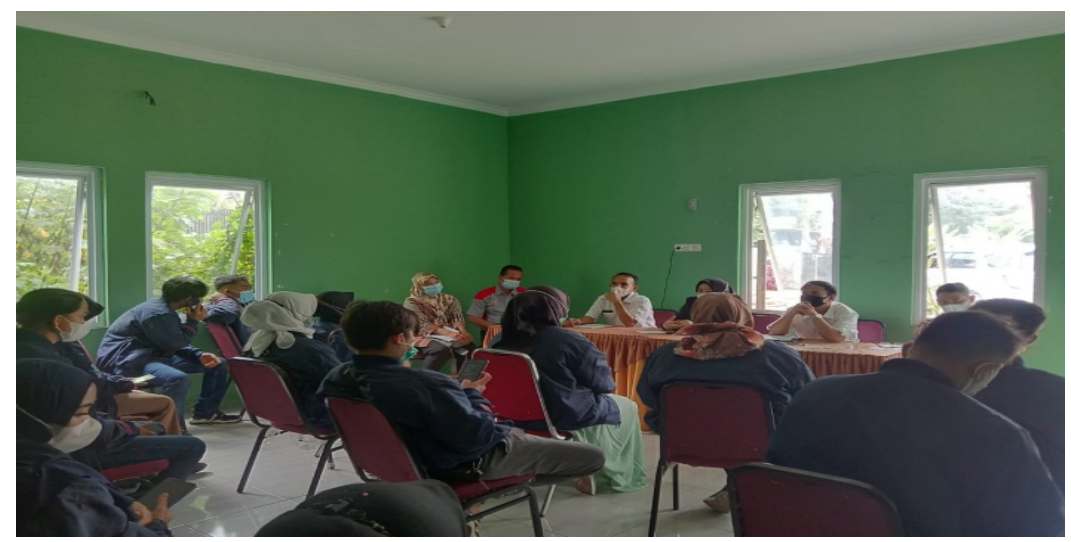

Gambar 1. Sosialisasi Awal Kegiatan 


\section{Vol. 2. No. 1. Tahun 2022}

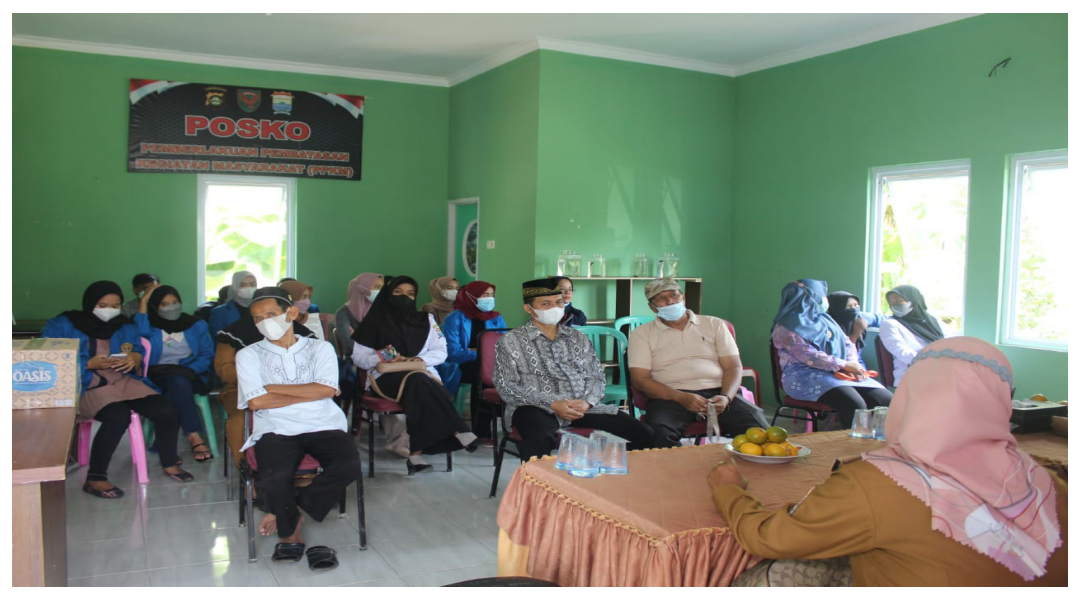

Gambar 2. Edukasi bersama Masyarakat dan Kelompok Tani

Gotong-royong sebagai solidaritas sosial yang terjadi dalam kehidupan masyarakat, terutama mereka yang membentuk komunitas-komunitas, karena dalam komunitas seperti ini akan terlihat dengan jelas. Gotong-royong terjadi dalam beberapa aktivitas kehidupan, Seperti gotong-royong dalam bentuk kerjabakti, dilakukan untuk kepentingan bersama. Kegiatan ini merupakan kegiatan yang bergerak dalam kegiatan sosial kemasyarakatan. (Siti Wahyuni, 2015)

Kegiatan ini dilakukan dengan maksud dan tujuan untuk memperindah lingkungan masyarakat dan membuat terlihat lebih bersih sehingga dapat terhindar dari serangan penyakit. Hasil yang ingin dicapai dari kegiatan ini adalah setelah dilakukannya gotong royong di Mushalla diharapkan Masyarakat menyadari pentingnya akan kebersihan demi kenyamanan dan kesehatan.

Mahasiswa berkerjasama dengan Masyarakat RW.001 untuk ikut memeriahkan dengan mengadakan beberapa lomba Kelurahan Sako Baru Kecamatan Sako Kota Palembang. Mengadakan aneka lomba seperti Lomba Makan Kerupuk, Lomba Kelereng, Lomba Joget Balon, Lomba Balap Karung, dan Lomba Mancing dalam Botol.

Hasil yang dicapai dalam program ini adalah dapat mempererat kebersamaan antara setiap warga RW.001 Kelurahan Sako Baru Kecamatan Sako Kota Palembang, serta menjalin keharmonisan antara Warga sekitar. Adapun Kegiatan Pemberdayaan Masyarakat dapat dilihat pada Gambar di bawah ini.

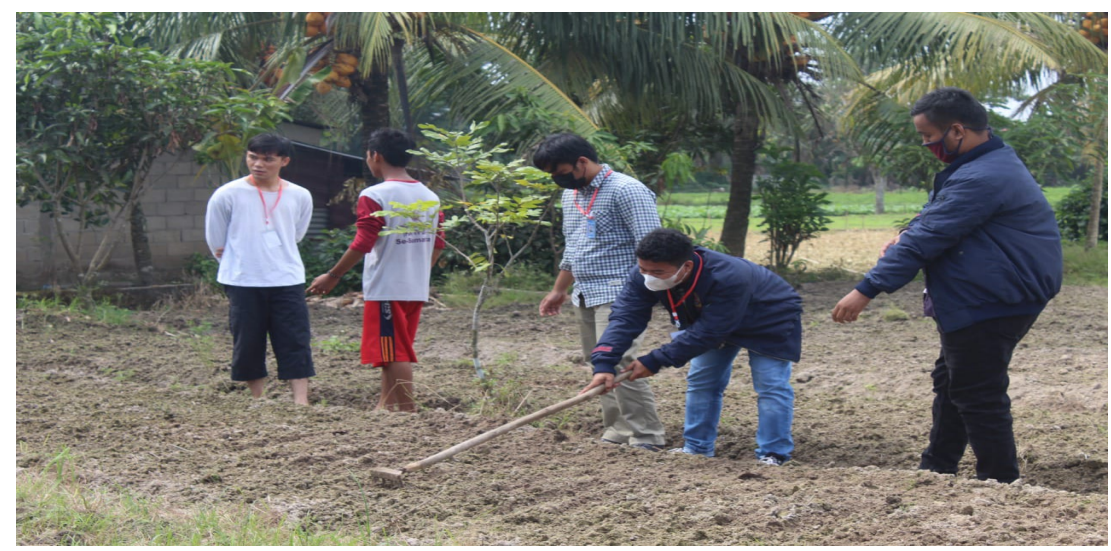

Gambar 3. Pembukaan lahan, persiapan bibit, dan persiapan pupuk 


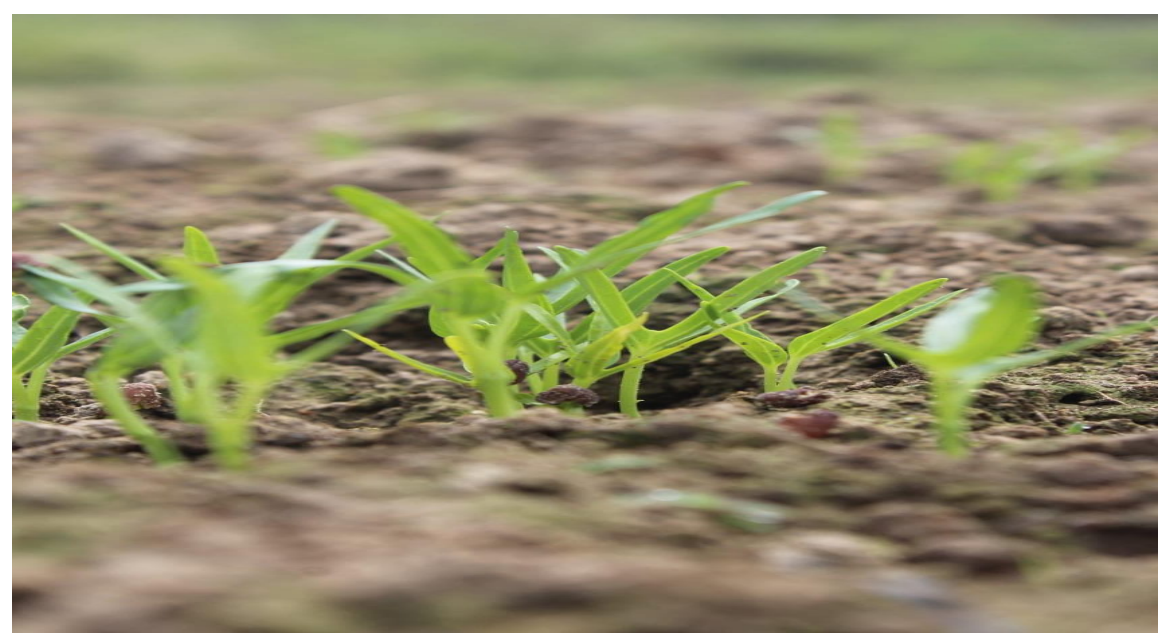

Gambar 4. Pertumbuhan Tanaman Sayur Kangkung

Peluang Program ini sangat bermanfaat dan membantu masyarakat sekitar dalam pemanfaatan lahan kosong yang ada di Kelurahan Sako Baru Kecamatan Sako Kota Palembang. Adapun kegiatan yang kami lakukan, tahap [1] Pemupukan, tanaman cukup dipupuk pada saat awal penanaman saja. Yaitu dengan menaburkan pupuk kandang atau pupuk kompos kemudian di diamkan selama 2 sampai 3 hari dengan takaran sesuai perhitungan. Namun jika tanaman kangkung terlihat kurang subur atau berwarna hijau pudar, maka kami perlu memberikan pupuk tambahan. Pemupukan tambahan bisa dilakukan dengan memberikan pupuk organik yang kaya akan nitrogen, bisa menggunakan kotoran ayam yang telah matang lalu dicampur dengan sekam atau kompos kaya nitrogen. [2] Penyiraman, Kangkung membutuhkan banyak air, masyarakat wajib rutin menyiraminya atau bisa dibuat irigasi kecil. Jika tanaman kangkung terlihat layu dan menguning di siang hari, juga perlu melakukan penyiraman dengan intensitas yang cukup. Kurangnya intensitas penyiraman air di siang hari bisa membuat tanaman kangkung mati. [3] Penyiangan, walaupun kangkung merupakan tanaman siklus cepat adakalanya tanaman muda kalah bersaing dengan rumput. Terutama saat penebaran benih awal, Pertumbuhan dari benih menjadi tanaman relatif agak lama sehingga potensi tersalip gulma (rumput liar) cukup tinggi. Apabila terjadi hal seperti ini, gulma tersebut harus cepat disingkirkan dengan dicabut. (Baranur, 2016)

Dalam melakukan budidaya kangkung, tentunya akan menemui beberapa kendala yang bisa mengganggu pertumbuhan tanaman tersebut. Salah satu kendala dalam penanaman kangkung yaitu tumbuhnya gulma di sekitar tanaman. Untuk itu harus rutin melakukan penyiangan atau pemberantasan gulma. Penyiangan ini dapat dilakukan setiap 2 minggu sekali dengan cara mencabut semua rumput liar atau gulma dengan tangan sampai gulmanya tak tersisa sedikitpun.

Ditengah pandemi covid 19 ini imunitas tubuh benar-benar harus dijaga dikarenakan penyerangan virus covid 19 mudah menyerang mereka yang memilki imunitas rendah. Banyak cara yang dapat digunakan untuk meningkatkan imunitas tubuh seperti berjemur dibawah matahari, olahraga dan makan makanan bergizi. Adapun manfaat dari kegiatan Pemberdayaan Masyarakat ini, membuat Masyarakat ikut serta penanaman sayur, membantu meningkatkan kebugaran jasmani, Mengembangkan keterampilan serta menanamkan nilai mental spiritual kepada individu yang melakukannya. (Rohana Zulmi, 2021) 


\section{Kesimpulan}

Kecamatan Sako baru mempunyai lahan yang luas yang dapat menjadi tanah perkebunan produktif menjadikan keunikan desa yang mana sayuran yang dihasilkan melimpah bagi warga sebagai bahan pokok dan bahan mata pencarian serta berkebun yang membantu perekonomian warga.

Kesimpulan yang dapat diambil dari pelaksanaan program ini yang berlokasikan Di kelurahan sako baru RW. 001 kecamatan sako kota Palembang ini adalah pemberian akses kepada Mahasiswa untuk langsung terjun pada Masyarakat dan menyalurkan ilmu yang didapat dari perkuliahan sehingga membantu masyarakat untuk membangun motivasi dan dapat menjadi wilayah yang produktif selama masa pandemi covid 19.

\section{Saran}

1. Meningkatkan tali silaturahmi dan hubungan kekerabatan serta interaksi kepada masyarakat Kelurahan sako baru dengan kelompok Tani.

2. Meningkatkan hubungan dengan sesame ketua RT di RW. 001.

3. Dalam penyusunan program hendaknya disesuaikan dengan situasi dan kondisi desa, pertimbangan dana, tenaga, dan waktu yang tersedia.

\section{Ucapan Terimakasih}

Kami mengucapkan terimakasih kepada semua pihak yang terkait, kepada:

1. Dr. Hj. Lishapsari Prihatini, M.Si, selaku Ketua STISIPOL Candradimuka Palembang.

2. Eka Gusdimantera. SH.M.Si, selaku Lurah dari Kantor Kelurahan Sako Baru Kecamatan Sako Kota Palembang

3. Bapak Samsul Bahri, selaku selaku ketua RT.001 di Kelurahan Sako Baru Kecamatan Sako Kota Palembang.

4. Bapak Ferry Adi, selaku pengurus Kelompok Tani di RT.001 Kelurahan Sako Baru Kecamatan Sako Kota Palembang.

5. Seluruh Mahasiswa yang terlibat selama Pemberdayaan Masyarakat berlangsung.

\section{Referensi}

Austin, T., \& Marleni. (2021). Implementasi Program Kampung Iklim: Urban Farming Melalui Hidroponik dan Budikdamber di Kelurahan Sialang Palembang. Jurnal Abdimas Indonesia, 1(3), 96-104.

Baranur. (2016). Budidaya Teknik dan Teknologi Pertanian. https://budidayateknikteknologipertanian.blogspot.com/2016/

Feriyanto. (2021). Profil Kecamatan. https://www.scribd.com/doc/148292015/ProfilKecamatan

Inang Pambudi, D., \& Yudha Erlangga, R. (2018). Pemanfaatan Lahan Kosong Sebagai Tanaman Obat Keluarga Warga Prancak Dukuh Panggungharjo, Sewon Bantul Yogyakarta. Jurnal Pemberdayaan: Publikasi Hasil Pengabdian Kepada Masyarakat, 2(2), 347-352. https://doi.org/https://doi.org/10.12928/jp.v2i2.462

Kementerian Lingkungan Hidup dan Kehutanan Direktorat Pengendalian Perubahan Iklim. (2017). Roadmap Program Kampung Iklim. https://www.scribd.com/document/403963110/roadmap-proklim-1-pdf. 
Rohana Zulmi. (2021). Senam Sehat Ceria Oleh Tim KKN-P 83 dan Karang Taruna Dusun Pateguhan Sebagai Penangkan Corona. https://drpm.umsida.ac.id/senam-sehatceria-oleh-tim-kkn-p-83-dan-karang-taruna-dusun-pateguhan-sebagaipenangkan-corona/

Siti Wahyuni. (2015). Pemanfaatan lahan kosong untuk pemanfaatkan penanaman sayur mayur. http://webblogkkn.unsyiah.ac.id/keutapangsanggeue9/2015/08/page/2/ 